\title{
Regional structure and kinematic history of the Sevier fold-and-thrust belt, central Utah: Discussion
}

\author{
Nicholas Christie-Blick ${ }^{\dagger}$ \\ Mark H. Anders \\ Department of Earth and Environmental Sciences and Lamont-Doherty Earth Observatory of Columbia University, Palisades, \\ New York 10964-8000, USA
}

DeCelles and Coogan (2006) summarize the structure and evolution of the Late Jurassic to Paleocene Sevier orogenic belt in central Utah, inferring at least $220 \mathrm{~km}$ of crustal shortening on the basis of a regional balanced cross section. Difficulties arise in an otherwise excellent synthesis in their treatment of the Sevier Desert basin, where $47 \mathrm{~km}$ of normal slip is interpreted on a Cenozoic detachment in spite of mounting evidence that no such structure exists (Anders and Christie-Blick, 1994; Hamilton, 1994; Anders et al., 1995, 1998, 2001; Wills and Anders, 1996, 1999; Wills, 2000; Hintze and Davis, 2003; Wills et al., 2005; Christie-Blick et al., 2007).

DeCelles and Coogan acknowledge the possibility that the prominent seismic reflection marking the Paleozoic-Cenozoic contact may correspond with an unconformity rather than a fault. However, they dismiss the inconvenient absence of evidence for deformation along the interpreted detachment as "local and equivocal," ignore a comprehensive re-evaluation of subsurface geophysical and geological data by Wills et al. (2005), and claim incorrectly that the construction of a balanced cross section "implicitly demonstrates the geometric and kinematic validity of the detachment interpretation for the .... reflection" (p. 844). Balanced cross sections are only as good as the observational constraints and assumptions upon which they are based. If the detachment that is a central assumption of DeCelles and Coogan's cross section (their Fig. 3) is, in fact, not a fault, a better section can be drawn.

The absence of evidence for fault-related deformation is hard to square with a crustally rooted structure accommodating many tens of kilometers of displacement (Anders and Christie-Blick, 1994; Anders et al., 1995, 2001). Microscopic studies of mineral particles in cuttings of mostly terrigenous Cenozoic basin fill from two wells in the southern Sevier Desert

†E-mail: ncb@1deo.columbia.edu. basin show no increase in the abundance of microfractures above background levels within $3 \mathrm{~m}$ of the hypothesized detachment, in spite of unambiguous ties to seismic reflection profiles crossing the wells. A more telling observation perhaps is that there is also no evidence for ductile deformation in a core of Paleozoic carbonate rocks recovered $12.8 \mathrm{~m}$ below the same contact or in cuttings from at least as close as $3 \mathrm{~m}$. A palinspastic reconstruction of $47 \mathrm{~km}$ of normal slip and any reasonable assumption of geothermal gradient places the latter samples well within the depth and temperature range at which mylonites should have developed in carbonate rocks (Anders et al., 2001).

A re-evaluation of geophysical and geological data from the Sevier Desert basin, including nearly $600 \mathrm{~km}$ of previously unavailable seismic reflection profiles, independently casts doubt on the interpreted detachment (Wills et al., 2005). The apparent continuity of a prominent seismic reflection from the Paleozoic-Cenozoic contact beneath the basin to within deformed Neoproterozoic and Paleozoic rocks of the Cricket Mountains block to the west is restricted to the northern part of the basin. In the south, the reflection terminates abruptly close to the Cricket Mountains. The feature with which it is approximately aligned in Consortium for Continental Reflection Profiling (COCORP) Utah Line 1 and in most industry profiles in the northern part of the basin is inferred by Wills et al. (2005) to correspond with splays of a thrust fault that places Lower Cambrian quartzite on top of Lower Cambrian siltstone and Upper Cambrian carbonate rocks in the Chevron Black Rock and Cominco American Federal wells (No. 1 and 2 in Figure 2 of DeCelles and Coogan, 2006). The fault, which is interpreted by us as the Pavant thrust, rises southward $\sim 2-3 \mathrm{~km}$ with respect to the base of the Sevier Desert basin. Both the Pavant thrust and a structurally higher fault that places Neoproterozoic quartzite and siltstone atop Lower Cambrian quartzite in the same wells, and is correlated with the Canyon Range thrust, are erosionally truncated at the western margin of the southern Sevier Desert basin. There is no consistent evidence that either fault terminates downwards against a detachment in the manner shown in Figure 3 of DeCelles and Coogan (2006). So those faults cannot be used to justify large normal-sense displacement or even the existence of a detachment. The projection of the Cominco American Federal well onto the critical part of the cross section is also misleading owing to the northward component of structural dip and the distance over which projection is needed (nearly $40 \mathrm{~km}$ ). Stratigraphic separation considerations suggest that the fault that DeCelles and Coogan identify as the Canyon Range thrust in that well is in any case the Pavant thrust (see above). Although the incomplete coverage and uneven quality of available seismic reflection data undoubtedly leave room for discussion about interpretive details, our interpretation is based on the tracing of reflections through the entire grid of available profiles and on ties to wells from profiles that in many instances pass directly over well locations.

Far from being necessary to explain the existence of the Sevier Desert basin, the detachment model is inconsistent also with seismically imaged stratal geometry and with evidence that the basin developed over at least 30 m.y. (see Lindsey et al., 1981; Mitchell and McDonald, 1987; Anders et al., 1998; Wills et al., 2005). Eastward-dipping strata labeled Olig. (Oligocene) by Von Tish et al. (1985; Fig. 3) and OligoceneQuaternary by DeCelles and Coogan (2006) in the same part of their Figure 3, are reinterpreted as Paleozoic and Neoproterozoic, based on an average velocity for the basin fill $\left(3.2 \mathrm{~km} \mathrm{~s}^{-1}\right)$ that is higher than originally assumed by Von Tish et al. at the nearby Gulf Gronning well, in which the Oligocene age is established, and for which no acoustic log data exist (Anders et al., 1995, 1998; Wills et al., 2005; No. 5 in Figure 2 of DeCelles and Coogan, 2006). Other seismic

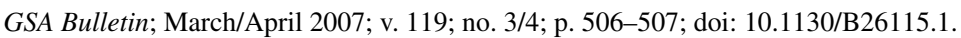


data and the orientation of stratification in core suggest that Oligocene deposits encountered in that well are subhorizontal (Anders et al., 1998; Wills et al., 2005). Widespread onlap at the western margin of the basin at all stratigraphic levels contrasts with the stratal growth that might be expected in a supradetachment basin. Instead, evidence for growth appears to be spatially and temporally localized in areas of intrabasinal salt tectonics. Moreover, if fission track ages of 19-15 Ma (apatite) and 13-11 Ma (zircon) from inferred footwall rocks in the Canyon Range and ARCO Meadow Federal well, respectively (No. 4 in Figure 2 of DeCelles and Coogan, 2006), relate to mid-Miocene and younger displacement along the hypothesized detachment (Allmendinger and Royse, 1995; Stockli et al., 2001), the significance of basin development prior to 19 Ma remains unexplained. And if the detachment developed during the Oligocene or even earlier, as seems to be required to account for the oldest basin fill (Anders et al., 2001) and to restore the pre-Cenozoic structure in the manner implied by Figure 8F of DeCelles and Coogan (2006), footwall uplift and exhumation are either not expressed in the fission track data or their timing was strangely delayed by at least 10 m.y. (Wills et al., 2005). A simple solution exists: there is no detachment. The fission track ages relate to exhumation of the Canyon Range by displacement on high-angle normal faults and to contemporaneous magmatism (Anders et al., 1995; Wills et al., 2005).

Reinterpretation of the Sevier Desert detachment as an unconformity fortuitously aligned west of the northern Sevier Desert basin with a Mesozoic thrust fault leads to several corollaries for DeCelles and Coogan's structural synthesis. (1) Total extension across the Sevier Desert basin is likely no more than a few kilometers, given that seismically imaged high-angle normal-fault offsets of the Paleozoic-Cenozoic contact are generally less than $750 \mathrm{~m}$ (Wills and Anders, 1999; Wills et al., 2005). (2) Estimates of crustal shortening, which are already subject to appreciable uncertainties with respect to the location of critical hanging-wall and footwall cutoffs, need to be revised. DeCelles and Coogan's figure of $\sim 117 \mathrm{~km}$ for overall shortening during emplacement of the Canyon Range thrust sheet, for example, should be increased by $40 \mathrm{~km}$ or more, to nearly $160 \mathrm{~km}$, because it depends on inferred cutoffs on opposite sides of the Sevier Desert. If correct, such large figures raise interesting issues about how slip is transferred onto other structures to the north and south, given what is known about displacement- length scaling relationships for individual faults (e.g., Schlische et al., 1996). (3) The broad culmination of crystalline basement that is generally regarded as an isostatic response to displacement on the purported detachment needs to be explained (Allmendinger and Royse, 1995; Coogan and DeCelles, 1998). The most reasonable hypothesis is that it relates to the incorporation of crystalline rocks in one or more thrust sheets in the manner explicitly recognized elsewhere in the Sevier belt by DeCelles (2004, p. 119) and many others (Anders et al., 1995). (4) A new explanation is required for the basin itself. Key elements of ideas explored by Wills et al. (2005) involve the development of $>2 \mathrm{~km}$ of erosional relief within the orogen, with the drainage system breaching generally resistant Neoproterozoic and Lower Cambrian rocks of the Canyon Range thrust sheet in the vicinity of the modern Sevier Desert; a transition to an internally drained depression (saline lake) in the Oligocene; and subsidence associated with midMiocene and younger high-angle normal faults.

As the article by DeCelles and Coogan (2006) makes clear, determining whether or not a detachment exists beneath the Sevier Desert is important for resolving details of the Sevier orogenic belt in the area for which it was named, as well as for elucidating how (and how much) crustal extension is accommodated in this part of the Basin and Range Province. Opinions entrenched by more than a decade of debate are not likely to be changed without new data. Therefore, we invite DeCelles, Coogan, and others interested in this geology to join us in advocating for a fully logged corehole through the basin so that our differences can finally be resolved. A workshop proposal was submitted to the International Continental Scientific Drilling Program in January 2007.

\section{REFERENCES CITED}

Allmendinger, R.W., and Royse, F., Jr., 1995, Is the Sevier Desert reflection of west-central Utah a normal fault?: Comment: Geology, v. 23, p. 669-670, doi: 10.1130/00917613(1995)023<0669:ITSDRO>2.3.CO;2.

Anders, M.H., and Christie-Blick, N., 1994, Is the Sevier Desert reflection of west-central Utah a normal fault?: Geology, v. 22, p. 771-774, doi: 10.1130/00917613(1994)022<0771:ITSDRO>2.3.CO;2.

Anders, M.H., Christie-Blick, N., and Wills, S., 1995, Is the Sevier Desert reflection of west-central Utah a normal fault?: Reply: Geology, v. 23, p. 670.

Anders, M.H., Christie-Blick, N., and Wills, S., 1998, Extensional collapse along the Sevier Desert reflection, northern Sevier Desert basin, western United States: Comment: Geology, v. 26, p. 474, doi: 10.1130/00917613(1998)026<0474:ECATSD>2.3.CO;2.

Anders, M.H., Christie-Blick, N., Wills, S., and Krueger, S.W., 2001, Rock deformation studies in the Mineral Mountains and Sevier Desert of west-central Utah:
Implications for upper crustal low-angle normal faulting: Geological Society of America Bulletin, v. 113 p. 895-907, doi: 10.1130/0016-7606(2001)113<0895: RDSITM $>2.0 . \mathrm{CO} ; 2$.

Christie-Blick, N., Anders, M.H., Wills, S., Walker, C.D, and Renik, B., 2007, Observations from the Basin and Range Province (western United States) pertinent to the interpretation of regional detachment faults, in Karner, G.D., Manatschal, G., and Pinheiro, L., eds., Imaging, Mapping and Modelling Continental Lithosphere Extension and Breakup: Geological Society of London Special Publication 282 (in press).

Coogan, J.C., and DeCelles, P.G., 1998, Extensional collapse along the Sevier Desert reflection, northern Sevier Desert basin, western United States: Reply: Geology, v. 26, p. 475, doi: 10.1130/0091-7613(1998)026<0475: DAKPFD $>2.3 . \mathrm{CO} ; 2$.

DeCelles, P.G., 2004, Late Jurassic to Eocene evolution of the Cordilleran thrust belt and foreland basin system, western USA: American Journal of Science, v. 304, p. 105-168, doi: 10.2475/ajs.304.2.105.

DeCelles, P.G., and Coogan, J.C., 2006, Regional structure and kinematic history of the Sevier fold-and-thrust belt, central Utah: Geological Society of America Bulletin, v. 118, p. 841-864, doi: 10.1130/B25759.1.

Hamilton, W., 1994, "Sevier Desert detachment," Utah-A nonexistent structure: Geological Society of America Abstracts with Programs, v. 26, no. 2, p. 57

Hintze, L.F., and Davis, F.D., 2003, Geology of Millard County, Utah: Utah Geological Survey Bulletin 133, $305 \mathrm{p}$.

Lindsey, D.A., Glanzman, R.K., Naeser, C.W., and Nichols, D.J., 1981, Upper Oligocene evaporites in basin fill of Sevier Desert region, western Utah: American Association of Petroleum Geologists Bulletin, v. 65, p. 251-260.

Mitchell, G.C., and McDonald, R.E., 1987, Subsurface Tertiary strata, origin, depositional model and hydrocarbon potential of the Sevier Desert basin, west central Utah, in Kopp, R.S., and Cohenour, R.E., eds., Cenozoic geology of western Utah-Sites for precious metal and hydrocarbon accumulations: Utah Geological Association Publication 16, p. 533-556.

Schlische, R.W., Young, S.S., Ackermann, R.V., and Gupta, A., 1996, Geometry and scaling relations of a population of very small rift-related normal faults: Geology, v. 24, p. 683-686, doi: 10.1130/0091-7613(1996)024<0683: GASROA $>2.3 . \mathrm{CO} ; 2$.

Stockli, D.F., Linn, J.K., Walker, J.D., and Dumitru, T.A., 2001, Miocene unroofing of the Canyon Range during extension along the Sevier Desert detachment, west central Utah: Tectonics, v. 20, p. 289-307, doi: 10.1029/2000TC001237.

Von Tish, D.B., Allmendinger, R.W., and Sharp, J.W., 1985 , History of Cenozoic extension in central Sevier Desert, west-central Utah, from COCORP seismic reflection data: American Association of Petroleum Geologists Bulletin, v. 69, p. 1077-1087.

Wills, S., 2000, Evaluating models of detachment faulting [Ph.D. thesis]: New York, Columbia University, 381 p.

Wills, S., and Anders, M.H., 1996, Western frontal fault of the Canyon Range: Is it the breakaway zone of the Sevier Desert detachment?: Comment: Geology, v. 24, p. 667-668, doi: 10.1130/0091-7613(1996)024<0667: WFFOTC $>2.3 . \mathrm{CO} ; 2$.

Wills, S., and Anders, M.H., 1999, Tertiary normal faulting in the Canyon Range, eastern Sevier Desert: The Journal of Geology, v. 107, p. 659-681, doi: 10.1086/314375.

Wills, S., Anders, M.H., and Christie-Blick, N., 2005, Pattern of Mesozoic thrust surfaces and Tertiary normal faults in the Sevier Desert subsurface, west-central Utah: American Journal of Science, v. 305, p. 42-100, doi: 10.2475/ajs.305.1.42.

Manuscript Received 28 SePtember 2006 MANUSCRIPT ACCEPTED 19 OCTOBER 2006

Printed in the USA 